\title{
Physical properties and biocompatibility of UHMWPE-derived materials modified by synchrotron radiation
}

\author{
Iu. Bykova $\cdot$ V. Weinhardt $\cdot$ A. Kashkarova $\cdot$ \\ S. Lebedev $\cdot$ T. Baumbach $\cdot$ V. Pichugin $\cdot$ \\ K. Zaitsev $\cdot$ I. Khlusov
}

Received: 13 January 2014/Accepted: 19 April 2014/Published online: 4 May 2014

(C) Springer Science+Business Media New York 2014

\begin{abstract}
The applications of synchrotron radiation (SR) in medical imaging have become of great use, particularly in angiography, bronchography, mammography, computed tomography, and X-ray microscopy. Thanks to recently developed phase contrast imaging techniques nondestructive preclinical testing of low absorbing materials such as polymers has become possible. The focus of the present work is characterization and examination of UHMWPE-derived materials widely used in medicine, before and after their exposure to SR during such testing. Physical properties, such as wettability, surface energy, IRspectroscopy, roughness, optical microscopy, microhardness measurements of UHMWPE samples were studied
\end{abstract}

\author{
Iu. Bykova $(\bowtie) \cdot$ A. Kashkarova $\cdot$ S. Lebedev $\cdot$ V. Pichugin . \\ I. Khlusov \\ Tomsk Polytechnic University, Lenin Ave. 30, 634050 Tomsk, \\ Russia \\ e-mail: yuliavb@tpu.ru \\ Iu. Bykova · T. Baumbach \\ Institute for Photon Science and Synchrotron Radiation, KIT, \\ 76344 Eggenstein-Leopoldshafen, Karlsruhe, Germany \\ V. Weinhardt \\ Centre for Organismal Studies, University of Heidelberg, Im \\ Neuenheimer Feld 230, 69120 Heidelberg, Germany \\ V. Weinhardt · T. Baumbach \\ Laboratory for Applications of Synchrotron Radiation, KIT, \\ 76128 Karlsruhe, Germany \\ K. Zaitsev \\ Tomsk Institute of Balneology and Physiotherapy, Rosa \\ Luxemburg str. 1, 634050 Tomsk, Russia \\ I. Khlusov \\ Siberian State Medical University, Moscow Tract 2, \\ 634050 Tomsk, Russia
}

before and after SR. The relationship between a growth of UHMWPE surface hydrophilicity after SR and surface colonization by stromal cells was studied in vitro. Obtained results demonstrate that SR may be used as prospective direction to examine bulk (porous) structure of polymer materials and/or to modify polymer surface and volume for tissue engineering.

\section{Introduction}

Biomaterials are natural or synthetic materials used as an interface with the biological environment in order to replace or to repair damaged tissue. Nowadays a key concept of tissue engineering is fabrication of natural or artificial material that acts as a template for cells providing structural support and guiding them to the newly formed tissue [1]. Thus, the main function of the tissue engineering material (scaffold) is to support the growing tissue by cells migration and proliferation. To fit these functions scaffold should possess appropriate characteristics: (1) mechanical competence (e.g., compressive and tensile strength); (2) porosity and external geometry; (3) chemical compatibility; (4) surface properties (e.g., surface energy, chemistry, charge, surface area); (5) high biocompatibility (absence of immunoreaction) [2]. All of these characteristics must be tailored to arrange for the requirements of different types of tissue [3]. Thus, a thorough characterization of scaffolds is essential in order to evaluate their biological suitability and to understand their biomechanical environment that will be favourable for cells $[4,5]$.

UHMWPE is actively used material for fabrication of sliding element in biomedical application. It is the material of choice for the loading bearing surfaces in the tibial plateau component in the total knee and acetabular cup one 
in the total hip prostheses due to wear resistant and low coefficient of friction over extended periods of time. The high molecular weight, between 2 and 6 million g/mol, results in a high resistance to mechanical stresses in comparison with other types of polyethylene (HDPE, LDPE, and others) [6]. Macro- and micropores as the defects of UHMWPE internal structure decrease its mechanical properties and increase failure rate dramatically. Therefore, nondestructive control of polymer compounds before and after implantation is a state of art for a prognosis of prosthesis fate.

On the other hand, pore size and distribution is a crucial point for biomedical efficiency of materials for tissue engineering, because it determines the cellular penetration, extracellular matrix production, and neovascularization of the inner areas of the scaffold [7].

Phase-contrast imaging with SR is successfully developing technique for biomedical nondestructive 3D visualization of weakly absorbing materials $[8,9]$, which provides qualitative and quantitative information about scaffold structure: porosity, pores spatial distribution, and tissue ingrowths [10]. But the radiation effects on the structure of polymer, breaks polymer chains and create free radicals [11, 12]. That can lead to the change of the physical-mechanical properties of the irradiated polymer [13, 14].

It should be noted that there is a data on the effects of electron beams (EB) or gamma rays on the properties of UHMWPE. However, the impact of SR (typically $1-50 \mathrm{keV}$ ) is poorly studied although it is important when using the SR to visualize implants as ex situ as in situ.

The present work is focused on the characterization of physical properties of samples made from UHMWPE and its copolymers possessing porous or dense structure. SR is applied to analyze an inner architecture and microstructure of the samples and taking into account that radiation technique produce radiation damages of UHMWPE, its physical properties were studied after X-ray phase contrast microimaging [15]. Since the biocompatibility of implants is strictly related to the surface properties of material, the measurements of surface characteristics such as wettability, surface energy, roughness and micro hardness were carried out.

\section{Materials and methods}

\subsection{UHMWPE preparation}

The samples of UHMWPE and its copolymers used in the present work were produced by compression moulding technique and listed in Table 1. The fundamentals apply to the compression moulding of UHMWPE where the consolidation of the materials is a direct result of the heat, pressure and time combination [16].
Table 1 Fabricated UHMWPE-derived polymers

\begin{tabular}{|c|c|c|}
\hline $\begin{array}{l}\text { Sample } \\
\text { number }\end{array}$ & Materials & $\begin{array}{l}\text { Manufacturing conditions } \\
\text { (temperature, time, } \\
\text { pressure) }\end{array}$ \\
\hline 1 & $\begin{array}{l}\text { UHMWPE (JSC SIBUR } \\
\text { Holding, Tomskneftekhim } \\
\text { Ltd. Russia) }\end{array}$ & $170{ }^{\circ} \mathrm{C} ; 3 \mathrm{~h} ; 15 \mathrm{kN}$ \\
\hline 2 & $\begin{array}{l}90 \mathrm{wt} \% \text { UHMWPE } \\
(\text { GUR4022) }+10 \mathrm{wt} \% \\
\text { PVDF }\end{array}$ & \\
\hline 3 & GUR4022 (Ticona LLC) & \\
\hline 4 & $\begin{array}{l}90 \mathrm{wt} \% \\
\text { UHMWPE + } 10 \mathrm{wt} \% \\
\text { LDPE-g-SMA }\end{array}$ & \\
\hline 5 & $\begin{array}{l}80 \mathrm{wt} \% \\
\text { UHMWPE + } 20 \mathrm{wt} \% \\
\text { LDPE-g-SMA }\end{array}$ & \\
\hline
\end{tabular}

UHMWPE powder at the mould was pressed at a controlled rate $(15 \mathrm{kN})$, and temperature $170{ }^{\circ} \mathrm{C}$ was applied to the mould using electrically heated system. Pure UHMWPE is difficult to process due to high viscosity. To facilitate its processing, UHMWPE was combined with short chain polymers such as LDPE and PVDF. For the higher stability, adhesion and mechanical properties improvement of obtained copolymers styrene maleic anhydride (SMA) was used as a reactive group. It is chemically bound to the polymer components of the mixture to form covalent physical and chemical bonds, significantly reducing the interfacial energy between different polymers. For fabrication of samples with a porous structure powder UHMWPE GUR4022 (Ticona LLC) were used. An average particle size is $120-150 \mu \mathrm{m}$, the density of the polymer is around $55 \mathrm{~g} / \mathrm{cm}^{3}$.

The formed polymers and copolymers possessed both porous and dense internal structure. The materials had a shape of round or rectangular plates with the thickness of around $0.8-1 \mathrm{~mm}$, that were divided into square samples of $1 \times 1 \mathrm{~cm}^{2}$ size. All samples were cleaned in an ultrasonic bath with ethanol and then in distilled water, then dried on the air prior to the tests.

All samples underwent irradiation by X-ray beam with a photon energy in the range of $1-50 \mathrm{keV}$ (TopoTomo beamline, ANKA light source) SR with dose rate of (0.6-0.8) Gy/s at room temperature in air. According to the designed experimental conditions the specimens were exposed to the dose of (3-4) kGys.

\subsection{Research methods}

Contact angle was measured with Contact Angle Measuring Module DSA20 EasyDrop (KRÜSS) using static sessile drop method at room temperature. For every measurement 
$3 \mu \mathrm{L}$ of liquid was dropped on the material surface by the syringe. The contact angle was calculated for one second after placing a drop on the surface by the software using image of the droplet. The calculation of the surface energy was made by Owens, Wendt, Rabel and Kaelble (OWRK) method, which was performed using two liquids: deionized water and glycerin $[17,18]$.

To identify chemical bonds, presented in the polymers, infrared (IR) spectroscopy was used in these studies. It is a versatile physical method for study of the structural features of organic and inorganic compounds. The Fourier transform infrared (FTIR) spectra of the UHMWPE samples before and after radiation were recorded in the wavelength range of 4,000-400 $\mathrm{cm}$ using Nicolet Termo 5700. Infrared spectroscopy spectra of all samples were measured in the transmission mode.

Measurements of polymer roughness, receiving profile, including micrographs were performed on profilometerprofilograph Talysurf (Talysurf Model 120 stylus profiler Taylor-Hobson, UK). It was used to determine the roughness of surface and present the results in the form of a curve (profilograms) characterizing the waviness and roughness of the surface. For each sample five measurements were made and the $R_{a}$, the average of the absolute surface profile value, determined by taking the average of those five values.

Surface roughness at the nanoscale was investigated with atomic force microscopy (AFM) on a Solver HV instrument (NT-MDT, Russia). The maximum limit of the vertical resolution was $6 \mu \mathrm{m}$ with the scan size of $50 \times 50 \mu \mathrm{m}$. The images were acquired at the scan frequency of $0.8 \mathrm{~Hz}$ with 256 lines. The surfaces of all samples before and after irradiation were analyzed by AFM. The measurements were repeated for six different areas on all samples, the average height on each scan area were analyzed and used as an average roughness value $S_{a}$ [19].

In practice the complex tests for tensile, impact strength and other parameters are often replaced by hardness tests that are performed significantly faster and costless. In present work microhardness was measured by Vickers microhardness tests (PMT-3 apparatus). The measurement of material hardness by this method is conducted using the four-sided diamond pyramid indenter with an apex angle of $136^{\circ}$, which is pressed into the face of the tested material under a controlled load. After removing the load the diagonals of square imprint, left on the surface of the sample, are measured. For the quantitative hardness characterization, the load was taken in relation to the magnitude of indentation (dent body).

\subsection{Cell culture in vitro testing}

The prenatal stromal cells isolated from human lung (HLPSC) with $\mathrm{CD}_{4} 4^{-} \mathrm{CD} 44^{+}$osteocalcin $^{-}$phenotype (Stem Cell Bank Ltd., Tomsk, Russia) were used as earlier tested specimen to study stromal stem cells osteogenic differentiation and maturation induced by calcium phosphate coatings [18]. After being unfrozen, $90 \%$ cells viability of HLPSC was identified in accordance with ISO 10993-5 test, $0.4 \%$ trypan blue being in use.

Each tested UHMWPE sample $(10 \mathrm{~mm} \times 10 \mathrm{~mm} \times 0.5 \mathrm{~mm}$ plates) was placed into each plastic well of 24-well plate (Orange Scientific, Belgium). HLPSC suspension was freshly prepared with a concentration of $3 \times 10^{4}$ viable karyocytes $/ \mathrm{mL}$ of the following culture medium: $80 \%$ of DMEM/F12 (1:1) (Gibco, USA), $20 \%$ of fetal bovine serum (Sigma-Aldrich, USA), $50 \mathrm{mg} / \mathrm{L}$ of gentamicin (Invitrogen, UK) and freshly added L-glutamine sterile solution in final concentration of $280 \mathrm{mg} / \mathrm{L}$ (SigmaAldrich, USA). The cell suspension was added in a volume of $1 \mathrm{~mL}$ per well. Cell culture was incubated during 5 days in a humidified atmosphere of $95 \%$ air and $5 \% \mathrm{CO}_{2}$ at $37{ }^{\circ} \mathrm{C}$. When cell monolayer formation around the samples was achieved by visual control cell culturing was stopped. HLPSC culture without the polymer samples served as control of cell growth.

Plastic wells and UHMWPE samples with adherent cells were continuously air-dried, fixed for $30 \mathrm{~s}$ in formalin vapors. Cell monolayer on UHMWPE samples was Giemsa stained by standard protocol. Alkaline phosphatase (ALP) staining of cells adhered to plastic wells was performed as described earlier [20]. Blue sites of enzymatic activity served as cellular ALP staining criteria. The staining was performed with ALP as it serves as a marker of maturation [21] and osteogenic differentiation of stromal stem cells [22]. Proliferation and osteoblastic differentiation of stromal stem cells are often used for in vitro biocompatibility assessments of the (polymer) scaffolds [23].

Axioskop 40 microscope (Carl Zeiss, Germany) was in use to analyze cells adhered to plastic. Digital images (14 megapixels resolution) of ALP-stained cells were done by Canon PowerShot A 630 camera. The magnification of $100 \times$ was applied.

Computer morphometry method was used to recognize quantitative parameters (number of stained cells, area of cell layer on the sample's surface) of the cells. To process digital images of stained cells ImageJ 1.43 program (http:// www.rsb.info.nih.gov/ij) was used. A number of ALPstained cells was calculated on images randomly selected for each plastic well. Cell layer areas stained by Giemsa were counted on the digital images ( 8 megapixels resolution) of UHMWPE surface as well.

\subsection{Statistics}

The obtained data were showed as the mean $(\mathrm{X})$, a standard deviation (SD), and a standard error of mean (m). To analyze the available data sets a normal distribution 
Table 2 Main characteristics of investigated scaffolds

\begin{tabular}{|c|c|c|c|c|c|c|}
\hline \multirow[t]{2}{*}{ Sample } & \multicolumn{3}{|l|}{ Before SR } & \multicolumn{3}{|c|}{ After exposure to SR } \\
\hline & $\begin{array}{l}1 \\
<H>(\mathrm{Mpa})\end{array}$ & $\begin{array}{l}2 \\
<d>(\mu \mathrm{m})\end{array}$ & $\begin{array}{l}3 \\
\text { Porosity }(\%)\end{array}$ & $\begin{array}{l}4 \\
<H>(\mathrm{Mpa})\end{array}$ & $\begin{array}{l}5 \\
<d>(\mu \mathrm{m})\end{array}$ & $\begin{array}{l}6 \\
\text { Porosity (\%) }\end{array}$ \\
\hline UHMWPE & $155 \pm 4$ & - & - & $246 \pm 2$ & - & - \\
\hline $90 \mathrm{wt} \%$ GUR4022 +10 wt $\%$ PVDF & $173 \pm 10$ & $109 \pm 9$ & 15 & $179 \pm 4$ & $109 \pm 9$ & 15 \\
\hline GUR4022 & $134 \pm 4$ & $84 \pm 5$ & 15 & $161 \pm 8$ & $84 \pm 5$ & 15 \\
\hline $80 \mathrm{wt} \%$ UHMWPE + $20 \mathrm{wt} \%$ LDPE-g-SMA & $120 \pm 20$ & - & - & $251 \pm 15$ & - & - \\
\hline $80 \mathrm{wt} \%$ UHMWPE $+20 \mathrm{wt} \%$ LDPE-modification & $94 \pm 20$ & - & - & $95 \pm 8$ & - & - \\
\hline
\end{tabular}

$<H>$ microhardness, $<d>$ mean diameter of the pore

Kolmogorov-Smirnov test has been used. Statistical differences were estimated with the help of Mann-Whitney's $U$-test and Wilcoxon's $T$-test. Spearman's rank order correlation coefficients $\left(\mathrm{r}_{\mathrm{S}}\right)$ were determined.

\section{Results and discussion}

\subsection{Physical properties}

Polymeric materials are investigated and characterized in terms of their developing manufacture and application as biomedical devices that include orthopedic, dental, soft tissue, and cardiovascular application.

The samples of UHMWPE (\#2 and \#3), which were formed using porogen materials GUR4022, possess the higher $R_{a}$ indices (Table 2). Roughness is a desirable feature for cell adhesion because of extensive area of contact with the substrate than on a smooth surface. Consequently, a lot of new receptors are implemented and the cell attachment to the surface is stronger. The roughness also affects the processes of cell migration and the spreading of adherent cells on the surface [24]. The two-dimensional (2D) sample's porosity was obtained by optical microscopy (Image size: $634 \times 589$ pixel $^{2}, 1,775 \times 1,649 \mu \mathrm{m}^{2}$ ).

Figure 1 demonstrates the pore size distribution for $2 \mathrm{D}$ optical image of GUR4022 sample \#3 with porogen elements. It has no homogeneous topography that influences the roughness level. The pores on the sample surface have a roughly rounded form with the mean diameter $109 \pm 9 \mu \mathrm{m}$. The same porous structure is observed for sample \#2. For other samples the morphology of surface regions does not possess similar inhomogeneous structure. Main characteristics of investigated scaffolds are presented in Table 2. Mean radius of the pores is calculated from 2D optical image (Table 2, columns 3 and 6) of UHMWPE.

The results for size distribution shown In Fig. 1 demonstrates that $4 \%$ of pore size varies within $0-10 \mu \mathrm{m}, 39 \%$ with the pore diameter $10-30 \mu \mathrm{m}, 24 \%$ : $30-70 \mu \mathrm{m}, 18 \%$ :

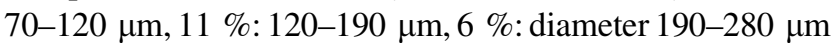

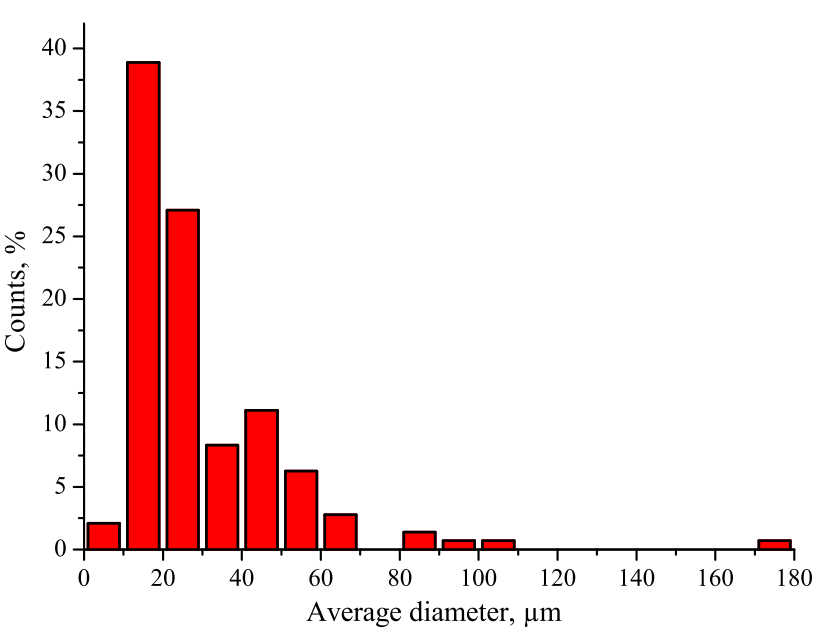

Fig. 1 Pore size distribution for 2D optical image of UHMWPE (90\% UHMWPE (GUR4022) + $10 \%$ PVDF)

and $6 \%$ of pore sizes are more than $280 \mu \mathrm{m}$. The porosity of the sample makes around $19 \%$ of the slice of material, while natural cartilage is a highly hydrated tissue, with a porosity varying from 68 to $85 \%$ in adult joints [25].

Stem cells and other types of cells (chondroblasts, osteoblasts, etc.) have real possibility to populate porous structure of samples tested. At the same time, natural cartilage has porosity varying from 68 to $85 \%$ in adult joints [26]. The pore size $<100 \mu \mathrm{m}$ and low porosity may potentially limit an access of nutrients to cells. On the other hand, decreasing the pore size improves the retention of the synthesized molecules of intercellular matrix [25].

It is necessary to create the material which not only restores the normal functions of injured articular cartilage, but also results in the formation of new tissue that is indistinguishable from the native cartilage. The rate of cell penetration and growth in polymeric porous structures is directly related to the pore size and distribution in the material and varies according to the size of the invading cells and the properties of the implant. That is why the pore distribution, their interconnectivity and size evaluation are significant point for biomaterial characterization. 
Table 3 The wettability of the investigated scaffolds

\begin{tabular}{|c|c|c|c|c|c|c|c|c|c|c|}
\hline & \multicolumn{5}{|c|}{ Before SR } & \multicolumn{5}{|c|}{ After exposure to SR } \\
\hline & 1 & 2 & 3 & 4 & 5 & 6 & 7 & 8 & 9 & 10 \\
\hline $\begin{array}{l}\text { Sample } \\
\text { number }\end{array}$ & $R_{a}(\mu \mathrm{m})$ & $\Theta_{w}^{\circ}$ & $\sigma\left(\mathrm{mJ} / \mathrm{m}^{2}\right)$ & $\sigma_{\mathrm{D}}\left(\mathrm{mJ} / \mathrm{m}^{2}\right)$ & $\sigma_{\mathrm{P}}\left(\mathrm{mJ} / \mathrm{m}^{2}\right)$ & $R_{a}(\mu \mathrm{m})$ & $\Theta_{w}^{\circ}$ & $\sigma\left(\mathrm{mJ} / \mathrm{m}^{2}\right)$ & $\sigma_{\mathrm{D}}\left(\mathrm{mJ} / \mathrm{m}^{2}\right)$ & $\sigma_{\mathrm{P}}\left(\mathrm{mJ} / \mathrm{m}^{2}\right)$ \\
\hline 1 & 0.116 & $99.4 \pm 2.0$ & $19.7 \pm 0.9$ & $17.0 \pm 0.5$ & $2.7 \pm 0.2$ & 0.119 & $80.2 \pm 3.5$ & $20.0 \pm 3.0$ & $12.6 \pm 1.4$ & $13.0 \pm 1.0$ \\
\hline 2 & 0.394 & $114.6 \pm 0.7$ & $22.2 \pm 0.9$ & $21.8 \pm 0.8$ & $0.4 \pm 0.1$ & 0.366 & $88.5 \pm 9.0$ & $48.0 \pm 5.0$ & $0.9 \pm 0.8$ & $47.0 \pm 4.5$ \\
\hline 3 & 0.373 & $100.0 \pm 2.0$ & $19.4 \pm 2.0$ & $17.3 \pm 1.8$ & $2.2 \pm 0.4$ & 0.621 & $88.5 \pm 0.9$ & $29.0 \pm 3.0$ & $25.0 \pm 3.0$ & $3.9 \pm 0.7$ \\
\hline 4 & 0.130 & $94.0 \pm 0.9$ & $17.0 \pm 2.0$ & $11.0 \pm 1.0$ & $6.7 \pm 0.7$ & 0.191 & $80.5 \pm 1.7$ & $25.0 \pm 5.0$ & $11.0 \pm 3.0$ & $14.0 \pm 2.0$ \\
\hline 5 & 0.274 & $97.3 \pm 2.0$ & $17.6 \pm 0.7$ & $13.4 \pm 0.5$ & $4.2 \pm 0.3$ & 0.236 & $87.5 \pm 0.8$ & $20.0 \pm 2.0$ & $4.6 \pm 0.9$ & $15.0 \pm 1.0$ \\
\hline
\end{tabular}

$R_{\mathrm{a}}$ roughness, $\Theta_{w}^{\circ}$ water contact angle, $\sigma$ surface energy, $\sigma_{\mathrm{D}}$ dispersive component of surface energy, $\sigma_{\mathrm{P}}$ polar component of surface energy

The wettability of biomaterials is a primary point for material characterization in vitro and in vivo because of all body tissues more or less interconnected with liquid media and body fluids. Wetting of biomaterial and surface energy varies as a dependence of chemical and structural aspects. Generally these features depend on microheterogeneity, topography, surface roughness, porosity, chemical composition and polarity of bonds [27].

Polymers should be hydrophilic, allowing a protein layer quickly adsorb on the scaffold surface upon contact with body fluid in vivo or culture medium in vitro to establish cell adhesion sites [28]. As it was established by us all received materials are hydrophobic, since the water contact angle varies from $98^{\circ}$ to $114^{\circ}$ (Table 3 , column 2).To reduce the hydrophobicity the surface of biopolymers should be modified, for example by electron, gamma or $\mathrm{X}$-ray radiation [28-31].

The change of contact angles can be explained by varied polar functionalities content $(-\mathrm{C}-\mathrm{O}-,-\mathrm{C}=\mathrm{O}$ and $-\mathrm{COO}-$ ). Also surface heterogeneity influences the results. The most hydrophobic polymers \#2 and \#3) with porogen elements possess a higher value of contact angle and $R_{a}$ measured at the macroscale (Table 3, column 1 and 2).

As it was shown in [32] several aspects affect the cell adhesion processes: chemical composition, surface charge and microstructural topography, but the result of the combination of these properties is not always clear. Polymers are known as low surface energy materials in comparison with ceramics and metals [32]. The values of measured surface energies varied between 20 and $30 \mathrm{~mJ} / \mathrm{m}^{2}$ (Table 3, column 3). Due to this fact microtopography plays a determinative role in a biocompatibility and possibility to regulate cell fate.

Polymer materials generally are nonpolar, for example polyethylene contains only $\mathrm{C}-\mathrm{H}$ and $\mathrm{C}-\mathrm{C}$ bonds, meaning that there are no oxygen bonds. However, low presence of such bonds is observed and the polar component of not irradiated polymers differs from zero (Table 3 , column 5). This amount can be attributed to very low oxidation level
Table 4 Radiation dose for polymer samples

\begin{tabular}{|c|c|c|c|}
\hline $\begin{array}{l}\text { Sample } \\
\text { number }\end{array}$ & Materials & $\begin{array}{l}\text { Dose } \\
\text { rate } \\
(\mathrm{Gy} / \mathrm{s})\end{array}$ & $\begin{array}{l}\text { Total dose }(\mathrm{kGy}) \\
\text { (time in } \\
\text { beam }=4,740 \mathrm{~s})\end{array}$ \\
\hline 1 & $\begin{array}{l}\text { UHMWPE } \\
\text { (Tomskneftekhim Ltd. } \\
\text { Russia) }\end{array}$ & 0.852 & 4.038 \\
\hline 2 & $\begin{array}{l}90 \mathrm{wt} \% \text { UHMWPE } \\
\text { (GUR4022) + } 10 \mathrm{wt} \% \\
\text { PVDF }\end{array}$ & 0.785 & 3.721 \\
\hline 3 & UHMWPE (GUR4022) & 0.665 & 3.152 \\
\hline 4 & $\begin{array}{l}90 \mathrm{wt} \% \\
\text { UHMWPE + } 10 \mathrm{wt} \% \\
\text { LDPE-g-SMA }\end{array}$ & 0.807 & 3.825 \\
\hline 5 & $\begin{array}{l}80 \mathrm{wt} \% \\
\text { UHMWPE + } 20 \mathrm{wt} \% \\
\text { LDPE-g-SMA }\end{array}$ & 0.834 & 3.953 \\
\hline
\end{tabular}

that is due to mechanical degradation occurring during sample preparation. Mechanical properties and stress resistance were evaluated due to microhardness test, which showed that the microhardnesses of UHMWPE porous samples \#2 and \#3 before irradiation are about 175 and $134 \mathrm{MPa}$, respectively (Table 2, column 2).

\subsection{Investigation of X-ray irradiated UHMWPE}

An important issue within X-ray tomography today is the radiation dose deposited in the sample during computer tomography (CT) examinations. The ionization processes, which occur because of X-rays interaction with material (Compton scattering, photoelectric absorption, etc.), can cause significant structural changes within the investigated sample. The dose was determined considering an exposure time of $15 \mathrm{~ms}$, read out time $\approx 700 \mathrm{~ms}$ and latency time of the turning motor $\approx 300 \mathrm{~ms}$ for each projection. The integrated dose for all samples for 1,500 projections is shown in Table 4. The average value of the dose is $\approx 3.7 \mathrm{kGy}$ (Table 4). 


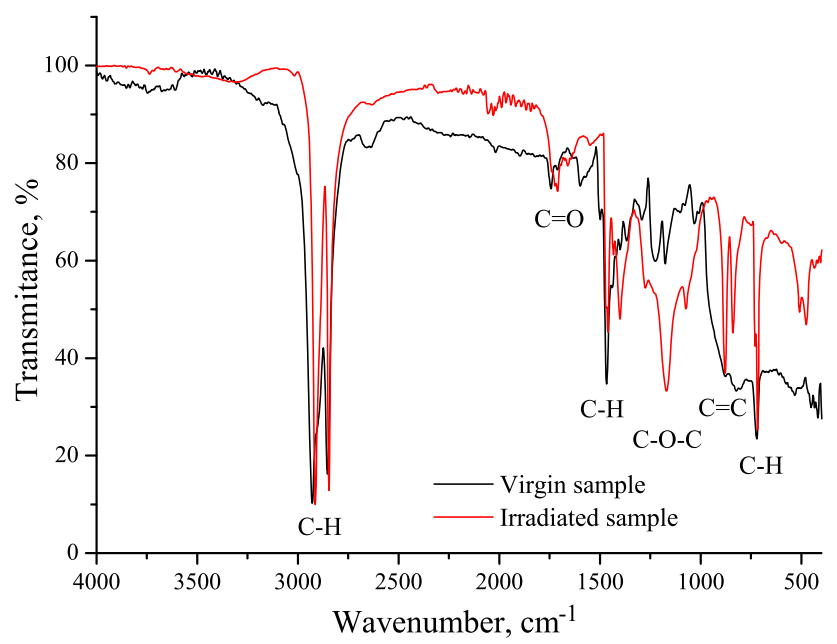

Fig. 2 The spectrum of UHMWPE before and after synchrotron radiation

The dose effect for UHMWPE is mainly formation of free radicals which leads to further structural changes in UHMWPE. The production of free radicals causes a loss of hydrogen and a rearrangement of the carbon bonds and form crosslinks, conformation changes, unsaturation and chain scissions. The free radicals can further react to form oxidized species and further chain scissioning in the presence of oxygen at and near the surface of the polymer [33,34]. If $\mathrm{C}-\mathrm{C}$ bonds of the polymer chain in UHMWPE are broken the $\mathrm{CH}_{2}$-radicals are formed, the molecular mass decreases; as a consequence, many of the chemical and physical properties of the polymer begin to worsen. The extent of the oxidative process depends on the number of radicals formed during irradiation and on the amount of oxygen, which can be atmospheric.

The main method for determination of the existence of crosslinks and insertion of oxygen in the structure of polyethylene is the use of FTIR spectroscopy. Infrared spectroscopy spectra of samples were measured in transmission mode (Fig. 2).

The most intensive vibrations are those arising from $\mathrm{C}-\mathrm{H}$ stretching and bending. Absorption arising from $\mathrm{C}-\mathrm{H}$ stretching occurs at 2,849 and 2,910 $\mathrm{cm}^{-1}$, and the bending vibrations of the $\mathrm{C}-\mathrm{H}$ bonds in the methylene groups are clearly visible at $1,462 \mathrm{~cm}^{-1}$. In addition, an increase in the absorbance in the $1,400-1,180 \mathrm{~cm}^{-1}$ region after SR exposure corresponds to the $\mathrm{C}-\mathrm{O}-\mathrm{C}$ vibrations and in the region from 800 to $1,100 \mathrm{~cm}^{-1}$ mostly related to unsaturated $\mathrm{C}-\mathrm{C}$ groups was noted. The peak in the FTIR spectra in the $1,700-1,750 \mathrm{~cm}^{-1}$ region signal associated with of carbonyl $(\mathrm{C}-\mathrm{O})$ groups related to oxidation, which is rather dependent of specimen degradation. For all this, oxidative effects influence physical properties of UHMWPE [10-14].

Typical AFM images of UHMWPE-derived polymer surfaces before and after SR irradiation are shown In Fig. 3.
The average roughness obtained from AFM images for nonirradiated sample \#2 is $S_{a}=215.5 \mathrm{~nm}$ and for sample \#3 is $S_{a}=61.1 \mathrm{~nm}$. After SR irradiation the average roughness for the sample \#2 is $S_{a}=203.7 \mathrm{~nm}$ and for sample \#3 is $S_{a}=81.4 \mathrm{~nm}$. The data demonstrate statistically non-significant change in the roughness of surfaces. This indicates that surface roughness has not been modified during X-ray imaging and changes observed in are due to chemical bonds reorganization.

Contact angle measurement showed the decrease of polymer hydrophobicity for all UHMWPE modifications. The change of contact angles of irradiated polymers is due to the formation of hydrophilic groups and equals to $11-20 \%$. Hydrophilic group formation is a process which includes two steps. The first one is the creation of free radicals on a polymer surface by the irradiation of any nature. The second step is an interaction between newly formed free radicals in polymer chains and oxygen and this processes result in the formation of polar groups such as carboxyl, carbonyl, hydroxyl and ester groups [13].

Figure 4 and data in Table 3 show the change in the surface free energy of UHMWPE after X-ray radiation. The surface free energy of all samples increases by 3-7 mJ/ $\mathrm{m}^{2}$ after SR (see Table 3, columns 3 and 8 ). Also, it was noticed that the radiation effectively increases the polar component, but dispersive component becomes smaller. The polar component increased in 2-8 times for different samples that was an evidence of oxidation processes occurring during irradiation (see Table 3, columns 4, 5 and 9, 10; and Fig. 4).

The contact angle and surface energy are the important characteristics of proteins adsorption and cell adhesion onto a biomaterial. Small water contact angles and high surface free energies indicate good adhesion properties of the material [31]. Obtained results of samples wettability after X-ray irradiation show that surface become more hydrophilic (Fig. 4). Surface energy increased (Fig. 4) that means a growth of polymer's bioactivity.

As it is known UHMWPE possess amorphous-crystalline structure [13]. Microhardness evaluation is a crucial point for the crystallinity level determination. In amorphous-crystalline polymers amorphous layers is a weak part of samples. Chains in these interlayers due to the fact that they are smaller in cross section than in the crystallites, overworked compared with the chains in the crystallites. Moreover, in the amorphous interlayers chains have different lengths and orientation, so the stresses are uneven. So it is natural to assume that the amorphous regions are responsible for the low strength of polymers [35].

Measurements illustrate that microhardness of the irradiated porous samples \#3 ( $\approx 195 \mathrm{MPa}$ for UHMWPE) is elevated as compared with not irradiated samples $(\approx 128 \mathrm{MPa})$. The same microhardness growth was noted 

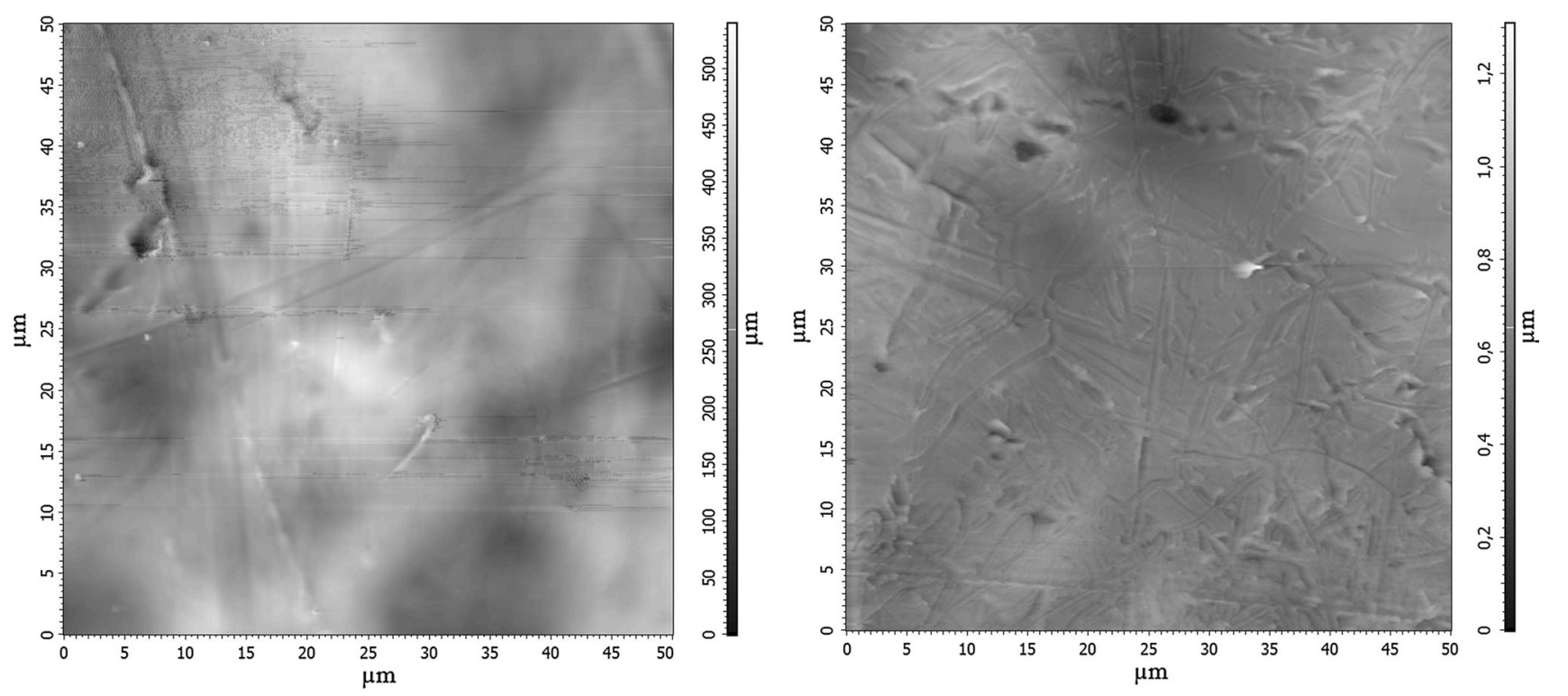

Fig. 3 AFM images of the surface of sample \#3 before and after synchrotron radiation
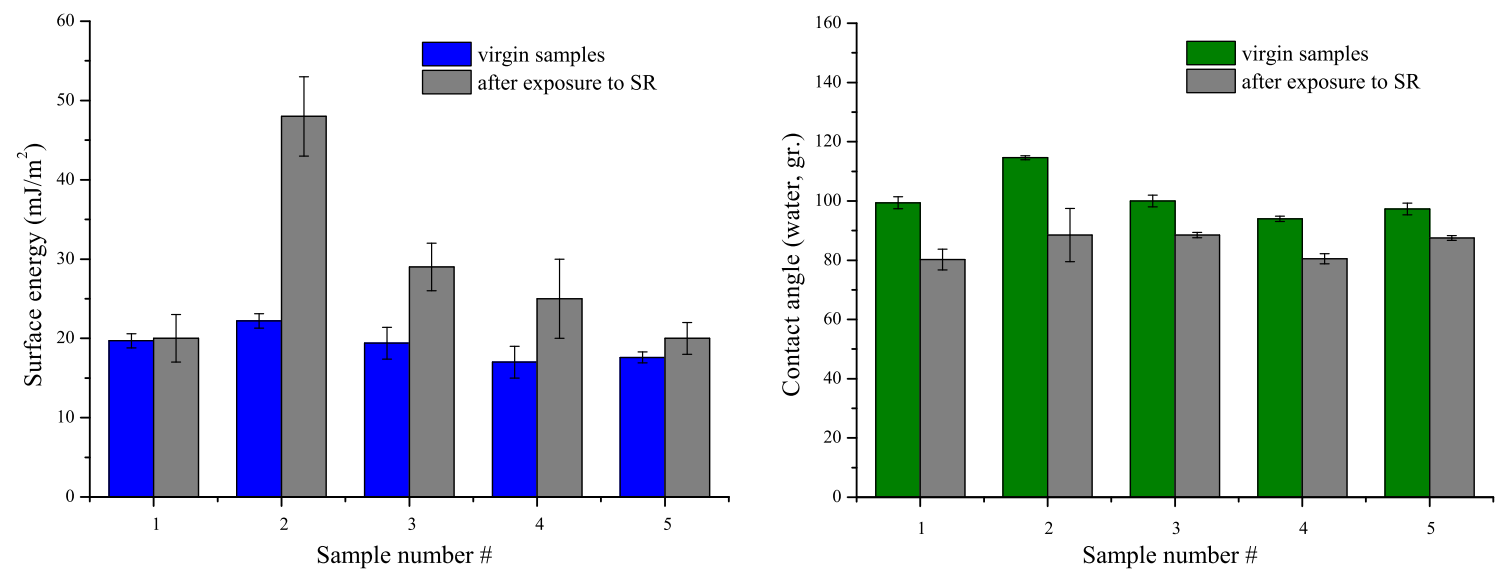

Fig. 4 Surface energy and contact angle measurements of the UHMWPE samples before and after SR

for X-ray irradiated UHMWPE porous sample \#2 (from ( $\approx 165 \mathrm{MPa}$ up to $200 \mathrm{MPa}$ ).

These results correspond to changes in optical density which evidence of decreased sample transparency due to crystallinity which increases the density of the material, reducing the speed of light and leading to an increase in the refractive index. These data allows concluding that processes of an oxidation caused by SR radiation accompanied with recrystallization and cross section change mechanical properties of the investigated UHMWPE samples.

\subsection{Cell monolayer formation}

The cell culture testing was performed on samples before and after SR. For virgin samples, fibroblast-like cell monolayer (Fig. 5a, b) and a number of ALP-stained cells
(Table 5) around the UHMWPE samples were equal to that in control (without sample) culture.

Nevertheless, there was visually marked formation of cell film on the sample \#3 only (Table 5). The low number of ALP-stained cells demonstrates weak attachment of HLPSC to virgin (before SR) surface of UHMWPEderived materials. Additionally, cells were concentrated mainly on the samples edges, where physicochemical properties of materials change dramatically [36].

No negative changes in cell monolayer features were noted for the synchrotron irradiated samples (Fig. 5c). Moreover, the number of ALP-stained cells was elevated statistically significant in the case of the sample \#3 (Table 5). Thus, an absence of cytotoxic products of UHMWPE degradation may be concluded.

It was shown that morphofunctional variations of cell culture around implants can be conditioned not only by 

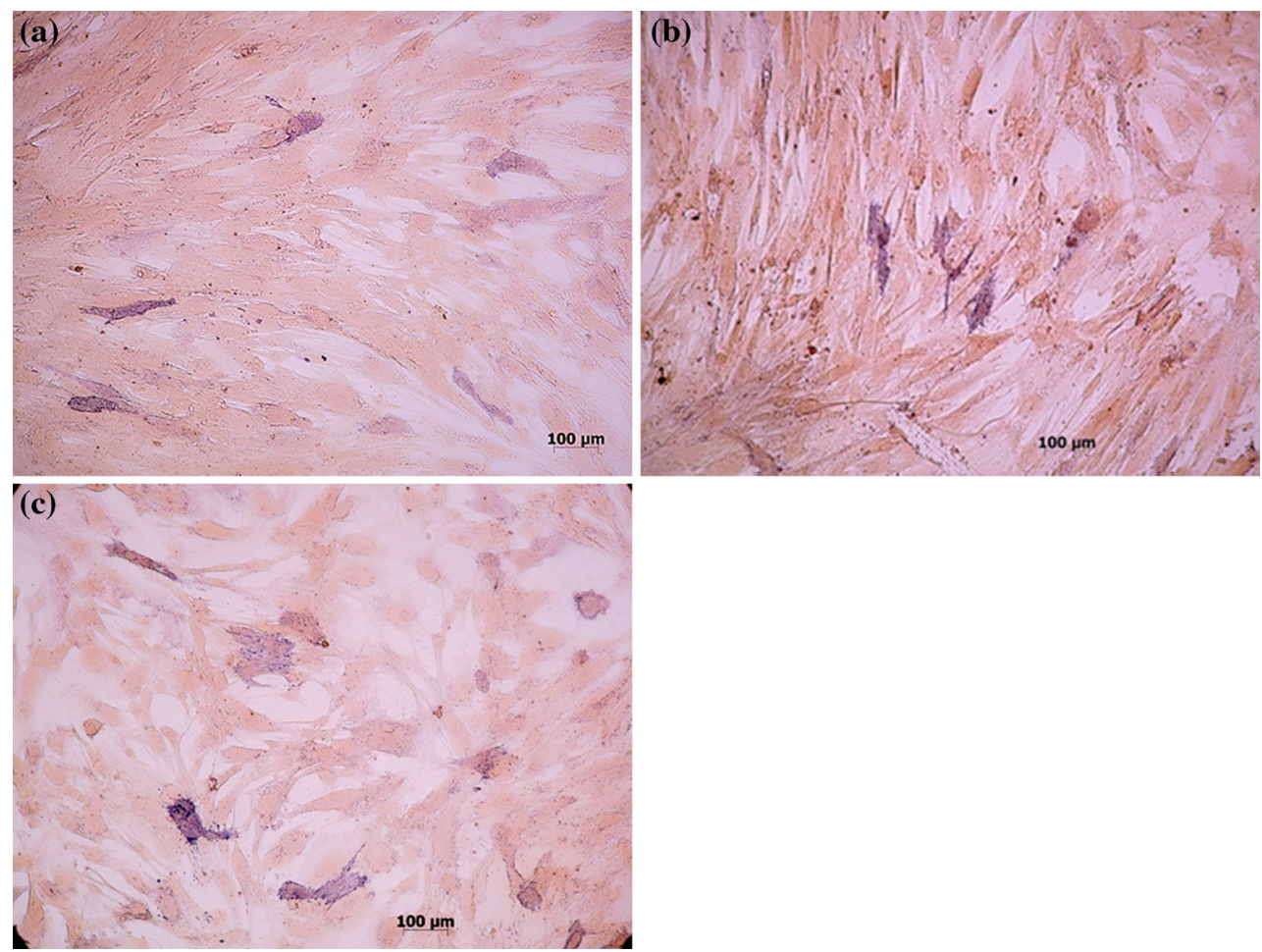

Fig. 5 Cell monolayer on plastic well in control (a) and around not irradiated (b) or after SR irradiation (c) UHMWPE samples. ALP-stained cells are blue. Magnification $100 \times$ (Color figure online)

Table 5 An average number of ALP-stained fibroblast-like cells on polystyrene plastic around UHMWPE samples before and after SR, $\mathrm{X} \pm \mathrm{SD}(\mathrm{m})$

\begin{tabular}{|c|c|c|c|}
\hline $\begin{array}{l}\text { Sample } \\
\text { number }\end{array}$ & Materials & $\begin{array}{l}\text { ALP-stained } \\
\text { cell amount } \\
\text { per } 1 \mathrm{~mm}^{2} \\
\text { before SR }\end{array}$ & $\begin{array}{l}\text { ALP-stained } \\
\text { cell amount } \\
\text { per } 1 \mathrm{~mm}^{2} \\
\text { after SR }\end{array}$ \\
\hline \multirow[t]{2}{*}{-} & \multirow[t]{2}{*}{$\begin{array}{l}\text { Plastic well (control } \\
\text { without sample tested) }\end{array}$} & $\begin{array}{l}3.83 \pm 1.72 \\
(0.32)\end{array}$ & - \\
\hline & & $n=29$ & \\
\hline \multirow[t]{2}{*}{2} & \multirow{2}{*}{$\begin{array}{l}90 \mathrm{wt} \% \text { UHMWPE } \\
\text { (GUR4022) + } 10 \mathrm{wt} \% \\
\text { PVDF }\end{array}$} & $\begin{array}{l}3.24 \pm 1.43 \\
(0.41)\end{array}$ & $\begin{array}{l}3.33 \pm 1.66 \\
(0.53)\end{array}$ \\
\hline & & $n=12$ & $n=10$ \\
\hline \multirow[t]{2}{*}{3} & \multirow[t]{2}{*}{ UHMWPE (GUR4022) } & $\begin{array}{l}2.97 \pm 1.42 \\
(0.43)\end{array}$ & $\begin{array}{l}4.38 \pm 1.71^{\mathrm{a}} \\
(0.47)\end{array}$ \\
\hline & & $n=11$ & $n=13$ \\
\hline \multirow[t]{2}{*}{4} & \multirow{2}{*}{$\begin{array}{l}90 \mathrm{wt} \% \\
\text { UHMWPE + } 10 \mathrm{wt} \% \\
\text { LDPE-g-SMA }\end{array}$} & $\begin{array}{l}3.09 \pm 1.33 \\
(0.40)\end{array}$ & $\begin{array}{l}4.55 \pm 2.38 \\
(0.72)\end{array}$ \\
\hline & & $n=11$ & $n=11$ \\
\hline
\end{tabular}

$n$ a number of digital images counted

${ }^{a}$ Statistical differences between the values before and after SR according to Mann-Whitney $U$ test

products of material's biodegradation, but also by a secretory reaction of the cells adhered to implants in dependence on the properties of their surface [37].
Therefore, radiation with SR led to more uniform distribution of cell film on the sample's surface. Cell layer areas increased and achieved statistical differences $(P<0.05 ; n=3)$ according to Wilcoxon's $T$ test (Table 6). No background uptake of Giemsa staining was found for samples without cells, before and after SR exposure (Table 6). Thus the increased cell layer is due to an alteration of physicochemical features of polymers after SR exposure.

The exposure of UHMWPE samples to SR caused surface hydrophilicity growth verified by decreasing contact angle of wettability (Fig. 4). Negative correlation $\left(\mathrm{r}_{\mathrm{S}}=-0.79\right.$; $P<0.05 ; n=6$ ) of the contact angle measurements and cell layer areas between virgin and irradiated samples was determined. Apparently, SR-conditioned increase in UHMWPE samples hydrophilicity (Fig. 4) promotes fibroblast-like cells colonization of their surface.

Furthermore, direct correlation $\left(\mathrm{r}_{\mathrm{S}}=0.83 ; P<0.04\right.$; $n=6)$ between cell layer area on the UHMWPE surface (Table 6) and a number of ALP-stained cells in monolayer around the sample (Table 5) was found before and after SR. These results show that SR-caused hydrophilicity of UHMWPE promotes morphofunctional alterations in HLPSC surrounding the polymer samples through the best colonization of their own surface.

In this work, the presence of SR-exposed UHMWPE scaffolds in HLPSC culture had indirect positive effect on 
Table 6 Areas of cell distribution on Giemsa stained UHMWPE samples surface before and after SR presented

\begin{tabular}{|c|c|c|c|c|c|}
\hline \multirow{2}{*}{$\begin{array}{l}\text { Sample } \\
\text { number }\end{array}$} & \multirow[t]{2}{*}{ Materials } & \multicolumn{2}{|c|}{ Before SR } & \multicolumn{2}{|l|}{ After SR } \\
\hline & & $\begin{array}{l}\text { Cell } \\
\text { layer } \\
\text { area }(\%)\end{array}$ & $\begin{array}{l}\text { Staining } \\
\text { without } \\
\text { cells }(\%)\end{array}$ & $\begin{array}{l}\text { Cell } \\
\text { layer } \\
\text { area }(\%)\end{array}$ & $\begin{array}{l}\text { Staining } \\
\text { without } \\
\text { cells }(\%)\end{array}$ \\
\hline 2 & $\begin{array}{l}90 \mathrm{wt} \% \text { UHMWPE (GUR4022) } \\
+10 \mathrm{wt} \% \text { PVDF }\end{array}$ & 25.5 & 0.0 & 27.0 & 0.0 \\
\hline 3 & UHMWPE (GUR4022) & 22.0 & 0.0 & 74.0 & 0.0 \\
\hline 4 & $\begin{array}{l}90 \text { wt } \% \text { UHMWPE + } 10 \text { wt } \% \\
\text { LDPE-g-SMA }\end{array}$ & 57.0 & 0.0 & 77.0 & 0.0 \\
\hline
\end{tabular}

the number of fibroblast-like cells, positively stained for ALP. The results showed that the possible degradation products of the scaffolds and factors secreted by cells interacting with them increased maturation and possible osteoblastic differentiation of human stromal cells. Statistically significant effect of SR-treated UHMWPE scaffolds in short-term culture is an evidence for their potential bioactivity and possible application for cartilage/bone interface engineering. It have to be noted however, that a number of other tests for biocompatibility, taking into account an estimation of the specificity and scope of medical applications, need to be further conducted in vitro and in vivo.

\section{Conclusion}

Recent development of phase contrast X-ray microtomography at synchrotron facilities have allowed as ex vivo and as in vivo non-destructive testing of polymer biomaterials. Using the SR to visualize implants require profound knowledge of radiation influence on physical properties of biomaterials and their biocompatibility. In this work, five various UHMWPE-derived materials before and after SR irradiation with the dose required to obtain three-dimensional phase contrast tomographic data have been studied.

The study of polymers after synchrotron radiation showed the chain scission and the free radicals formation in the UHMWPE derived materials. The IR-spectra and wettability data showed the evidence of the appearance of carbonyl and carboxyl chemical groups and an increase of the surface energy polar component proving the oxidation and reduction of the molecular weight, which would typically lead to degradation of material structure. On the contrary, the UHMWPE microhardness was increased by X-ray radiation, providing evidence of cross-linking that usually leads to three-dimensional network and renders it more resistant to mechanical stress in multiple directions. The relationship between a growth of UHMWPE surface hydrophilicity after SR and surface colonization by stromal cells demonstrated potential of irradiated polymers in bioactivity and possible application for cartilage/bone interface engineering.
The obtained data demonstrates that the SR may be used to crosslink UHMWPE prior to fabrication into its final form. Combined with three-dimensional structure information such as porosity, pores spatial distribution, and tissue ingrowths it might be potentially the most promising technique for preclinical characterization of polymer implants.

Acknowledgments We would like to thank Feng Chen, Dmitry Karpov, Franz Kuchling and Barbara Trimborn for their assistance during the measurements. We also thank ANKA and KNMF facility for the allocated beamtime. This work was supported by the Ministry of Education and Science RF, project No. 7.1084.2011 and by the German Federal Ministry of Education and Research under Grant numbers $05 \mathrm{~K} 12 \mathrm{CK} 2$ and $05 \mathrm{~K} 12 \mathrm{VH} 1$.

\section{References}

1. Graysona WL, Martensa TP, Enga GM, Radisic M, Vunjak-Novakovic $\mathrm{G}$. Biomimetic approach to tissue engineering. Semin Cell Dev Biol. 2009;20:665-73.

2. Capes JS, Ando HY, Cameron RE. Fabrication of polymeric scaffolds with a controlled distribution of pores. J Mater Sci Mater Med. 2005;16:1069-75.

3. Dhandayuthapani B, Yoshida Y, Maekawa T, Kumar DS. Polymeric scaffolds in tissue engineering application: a review. Int $\mathrm{J}$ Polym Sci. 2011;2011:1-19.

4. Ratner BD. Polymeric implants. Polym Sci. 2012;9:397-411.

5. Roohani-Esfahani SI, Dunstan CR, Lia JJ, Zufu Lu, Davies B, Pearce S, Field J, Williams R, Zreiqat $\mathrm{H}$. Unique microstructural design of ceramic scaffolds for bone regeneration under load. Acta Biomater. 2013;9(6):7014-24.

6. Kurtz Steven M. The UHMWPE handbook ultra-high molecular weight polyethylene in total joint replacement. San Francisco: Elsevier Academic Press; 2004. p. 379.

7. Renghini C, Giuliani A, Mazzoni S, Brun F, Larsson E, Bain F, Vitale-Brovarone C. Microstructural characterization and in vitro bioactivity of porous glass-ceramic scaffolds for bone regeneration by synchrotron radiation X-ray microtomography. J Eur Ceram Soc. 2012;2012:1-13.

8. Baruchel J, Buffiere J-Y, Cloetens P, Di Michiel M, Ferrie E, Ludwig W, Maireb E, Salvo L. Advances in synchrotron radiation microtomography. Scripta Mater. 2006;55:41-6.

9. Betz O, Wegst U, Weide D, Heethoff M, Helfen L, Lee W-K, Cloetens P. Imaging applications of synchrotron X-ray phasecontrast microtomography in biological morphology and biomaterials science. I. General aspects of the technique and its advantages in the analysis of millimetre-sized arthropod structure. J Microsc. 2007;227(1):51-71. 
10. Cancedda R, Cedola A, Giuliani A, Komlev V, Lagomarsino S, Mastrogiacomo M, Peyrin F, Rustichelli F. Bulk and interface investigations of scaffolds and tissue-engineered bones by X-ray microtomography and X-ray microdiffraction. Biomaterials. 2007;28:2505-24.

11. Kang $\mathrm{PH}$, Nho YC. The effect of $\gamma$-irradiation on ultra-high molecular weight polyethylene recrystallized under different cooling conditions. Radiat Phys Chem. 2001;60:79-87.

12. Bozorg Haddad M, Ebrahimi NG. Effect of radiation on the properties of UHMWPE/PET. Compos Iran Polym J. 2006;15(3): 195-205.

13. Kurtz SM. Ultra high molecular weight polyethylene in total joint replacement and medical devices. San Diego: Academic Press; 2009. p. 568.

14. Kurtz SM. PEEK biomaterials handbook. Norwich: William Andrew is an imprint of Elsevier; 2011. p. 306.

15. McKellop H, Shen FW, Lu B, Campbell P, Salovey R. Effect of sterilization method and other modifications on the wear resistance of acetabular cups made of ultra-high molecular weight polyethylene. A hip-simulator study. J Bone Joint Surg Am. 2000;82-A:1708-25.

16. Allen M. UHMWPE processing: techniques and problem. UHMWPE for Arthroplasty: Past, Present, and Future. 2003;20-31.

17. Żenkiewicz M. Methods for the calculation of surface free energy of solids. J Achiev Mater Manuf Eng. 2007;24(1):137-45.

18. Owens DK, Wendt RC. Estimation of the surface free energy of polymers. J Appl Polym Sci. 1969;13:1741-7.

19. Löberg J, Mattisson I, Hansson S, Ahlberg E. Characterisation of titanium dental implants I: critical assessment of surface roughness parameters. Open Biomater J. 2010;2:18-35.

20. Khlusov IA, Shevtsova NM, Khlusova MY. Detection in vitro and quantitative estimation of artificial microterritories which promote osteogenic differentiation and maturation of stromal stem cells. Methods Mol Biol. 2013;1035:103-19.

21. He Q, Wan C, Li G. Concise review: multipotent mesenchymal stromal cells in blood. Stem Cells. 2007;25:69-77.

22. Friedenstein AJ. Osteogenic stem cells in bone marrow. In: Heershe JNM, Kanis JA, editors. Bone and mineral research. Amsterdam: Elsevier Science Publishers; 1990.

23. Lee HY, Jin GZ, Shin US, Kim JH, Kim HW. Novel porous scaffolds of poly(lactic acid) produced by phase-separation using room temperature ionic liquid and the assessments of biocompatibility. J Mater Sci Mater Med. 2012;23(5):1271-9. doi:10.1007/s10856012-4588-4.
24. Dee Kay C, Puleo David A, Bizios Rena. An introduction to tissue-biomaterial interactions. Etobicoke: Wiley; 2002. p. 248.

25. Grad S, Gorna K, Gogolewski S, Alini M. Scaffolds for cartilage tissue engineering: effect of pore size. Eur Cells Mater. 2004;7:1-3.

26. Ateshian GA, Hung CT. The natural synovial joint: properties of cartilage. Proc IMechE Part J. 2006;220:657-70.

27. Lim JY, Donahue HJ. Biomaterial characteristics important to skeletal tissue engineering. J Musculoskel Neuron Interact. 2004;4(4):396-8.

28. Steward AJ, Liu Y, Wagner DR. Engineering cell attachments to scaffolds in cartilage tissue engineering. Biomater Regen Med Eng. 2011;63:74-82.

29. Wu X, Wu C, Wang G, Jiang P, Zhang J. A crosslinking method of UHMWPE irradiated by electron beam using TMPTMA as radiosensitizer. J Appl Polym Sci. 2013;127(1):111-9.

30. Benson RS. Use of radiation in biomaterials science. Nucl Instrum Methods Phys Res. 2002;191:752-7.

31. Abdul-Kader AM, Turos A, Radwan RM, Kelany AM. Surface free energy of ultra-high molecular weight polyethylene modified by electron and gamma irradiation. Appl Surf Sci. 2009;255: 7786-90.

32. Hallab NJ, Bundy KJ, O'Connor K, Moses RL, Jacobs JJ. Evaluation of metallic and polymeric biomaterial surface energy and surface roughness characteristics for directed cell adhesion. Tissue Eng. 2001;7:55-71.

33. Buncick MC, Thomas DE, McKinny KS, Jahan MS. Structural changes of ultra-high molecular weight polyethylene exposed to $\mathrm{X}$-ray flux in X-ray photoelectron spectroscopy detected by valence band and electron spin resonance spectroscopy. Appl Surf Sci. 2000;156:97-109.

34. Bistolfi A, Bellare A. The relative effects of radiation crosslinking and type of counterface on the wear resistance of ultrahigh-molecular-weight polyethylene. Acta Biomater. 2011;7(9):3398-403.

35. Kanaga Karuppiah KS, Bruck AL, Sundararajan S, Wang J, Lin $\mathrm{Z}, \mathrm{Xu} \mathrm{Z}-\mathrm{H}, \mathrm{Li} \mathrm{X}$. Friction and wear behavior of ultra-high molecular weight polyethylene as a function of polymer crystallinity. Acta Biomater. 2008;4(5):1401-10.

36. Yu LMY, Leipzig ND, Shoichet MS. Promoting neuron adhesion and growth. Mater Today. 2008;11:36-43.

37. Schakenraad JM, Busscher HJ, Wildevuur ChRH, Arends J. Thermodynamic aspects of cell spreading on solid substrata. J Cell Biophys. 1988;13:75-91. 